\title{
AN ANALYTICAL STUDY ON THE DEPOSITION OF ALUMINUM FROM ETHYL BROMIDE SOLUTION
}

BY HARRISON EASTMAN PATTEN

\section{Introduction}

In I902 W. A. Plotnikoff made the interesting discovery that aluminum bromide dissolved in ethyl bromide yields a solution of exceptionally good conductivity. ${ }^{x} \mathrm{He}$ deposited crystalline aluminum from this solution upon a carbon electrode, but gave no conditions save the exclusion of moisture. As numerous attempts at depositing aluminum have failed or only partially succeeded, I have studied the electrolysis of this solution.

The factors to be considered are: temperature; concentration; anode and cathode potentials; electrode materials ; conductivity of solution; current density; film formation or passive state of aluminum; and the physical state of the deposit.

For convenience and clearness, the experimental work is presented under two divisions: (I) Total decomposition curves for a moderately concentrated solution; $(a)$ with polished platinum electrodes, $(b)$ with platinized platinum electrodes, both showing no aluminum deposited; $(c)$ with aluminum electrodes, and $(d)$ a curve showing the fall of potential of aluminum against platinum with time, which accounts for the non-corrosion of the aluminum anode observed in (c). (2) Anode, cathode, and total decomposition curves for platinum electrodes, in a concentrated solution from which aluminum was deposited at low current density.

\section{Experimental}

I.

Aluminum bromide, prepared by passing bromine vapor over heated aluminum in a current of carbon dioxide, was dissolved in anhydrous ethyl bromide. This solution showed a

\footnotetext{
${ }^{1}$ Jour. Russ. Phys. Chem. Soc. (3) 466 (Ig02).
} 
specific gravity of 1.405 at $20^{\circ} \mathrm{C}$, as compared with water at $4^{\circ} \mathrm{C}$. 7.586 grams of solution at this temperature gave $0.0635 \mathrm{~g} \mathrm{Al} \mathrm{Al}_{3}$, which corresponds to $0.3324 \mathrm{~g} \mathrm{AlBr}_{3}$, a percent of $4.3^{8}$ upon the total weight of solution. One gram-molecule of $\mathrm{AlBr}_{3}$ is contained in 4.34 liters, or one gram-equivalent in 1.43 liters. At $20.5^{\circ} \mathrm{C}$ the specific conductivity was $3.763 \times 10^{-4}$ reciprocal ohms (Kohlrausch method).

This solution was electrolyzed between platinized electrodes in a dry celli at $15^{\circ} \mathrm{C}$, the temperature being controlled by a water-bath. The method used to measure the impressed voltage and the corresponding current through the cell is given in a former paper. ${ }^{2}$ In. Table I $a$ the electromotive force was read by compensation, and the current calculated by taking the drop in voltage actoss a known resistance placed in series with the cell; in Table I $b$ a voltmeter was used and the current measured by a Weston milliammeter.

Table I a shows a well defined $C R$ line for low current densities, and a polarization value of 0.6 volt at about $0.000 \mathrm{I}$ ampere per square centimeter. Bromine is liberated at the anode. (A plate of aluminum after being allowed to coat itself by standing in the air gives 0.632 volt in this solution against a platinum cathode.)

Table $\mathrm{I} b$ shows that a solution of this low concentration does not yield metallic aluminum even at comparatively high current densities. The discharge potentials confirm this : 0.069 volt was obtained from a current density of 0.007 ampere per sq. $\mathrm{cm}$., and 0.263 volt from 0.033 ampere per sq. $\mathrm{cm}$., whereas deposited aluminum has a total discharge potential against platinum of 2.3 volts (in this solution) and a single potential of I.I volt again aluminum bromide in ethyl bromide, as will be shown below. The time which elapsed between the release of

${ }^{1}$ For dimensions of cell see "Single Potentials of Zinc, Etc." Patten and Mott. Trans. Am. Electrochem. Soc. 1903, Vol. III.

2 "Decomposition Curves of Lithium Chloride in Various Alcohols and the Electrodeposition of Lithium." Patten and Mott. Jour. Phys. Chem. March, I 904 . 
the impressed E. M. F. and the taking of the discharge potential was near one-tenth of a second.

TABLE I $a$.

$\mathrm{A} \mathrm{Br}_{3}$ in $\mathrm{C}_{2} \mathrm{H}_{5} \mathrm{Br} . \quad 4.3^{8}$ percent. $\quad t=\mathrm{I} 5^{\circ} \mathrm{C}$.

\begin{tabular}{c|l|l}
\hline Volts & Amperes & Amperes per sq. cm. \\
\hline 0.282 & 0.000072 & 0.000024 \\
0.535 & 0.000142 & 0.000047 \\
0.791 & 0.000769 & 0.000256 \\
0.930 & 0.00108 & 0.00036 \\
1.301 & 0.00228 & 0.00076 \\
1.408 & 0.00265 & 0.00088 \\
I.68I & 0.00345 & 0.001 .15
\end{tabular}

TABLE I $b$.

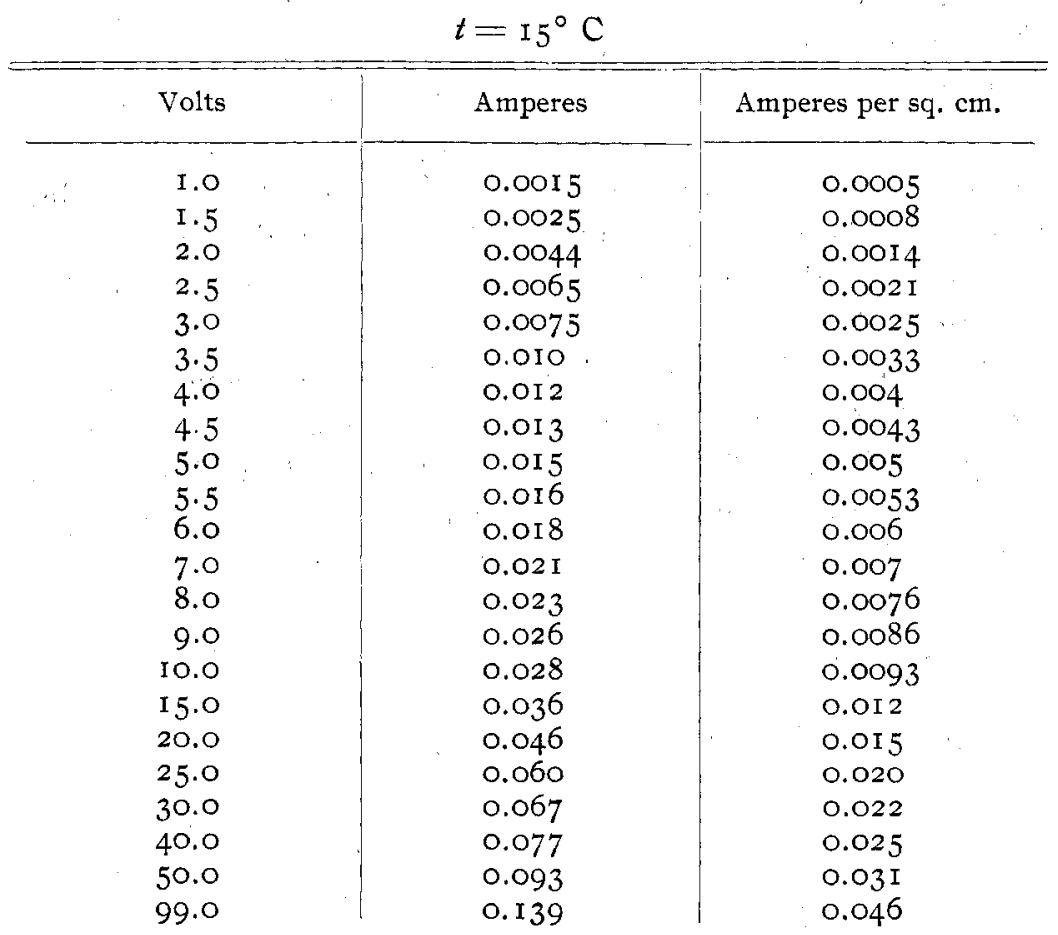

To ascertain the effect of surface condition of the platinum cathode upon the deposition of aluminum from this solution a 
second portion of this same solution was electrolyzed between polished platinum electrodes. Table II $a$ was taken by the potentiometer method used for Table I $a$ and there cited.

TABLE II $a$.

$\mathrm{A} 1 \mathrm{Br}_{3}$ in $\mathrm{C}_{2} \mathrm{H}_{5} \mathrm{Br} . \quad 4.3^{8}$ percent. $\quad t=\mathrm{I} 5^{\circ} \mathrm{C}$.

\begin{tabular}{c|l|l}
\hline Volts & Amperes & Amperes per sq. cm. \\
\hline 0.90 & 0.000238 & 0.000158 \\
1.60 & 0.000452 & 0.000301 \\
1.99 & 0.000602 & 0.000401 \\
2.90 & 0.00101 & 0.000674 \\
3.84 & 0.00156 & 0.00104 \\
4.80 & 0.00199 & 0.001326 \\
5.76 & 0.00241 & 0.001605 \\
6.70 & 0.00306 & 0.00204 \\
8.60 & 0.00405 & 0.0027 \\
11.44 & 0.00562 & 0.0037
\end{tabular}

TABLE II $b$.

\begin{tabular}{l|l|l}
\hline Volts & Amperes & Amperes per sq. cm. \\
\hline 10.0 & 0.005 & 0.00333 \\
15.0 & 0.0075 & 0.005 \\
20.0 & 0.0095 & 0.0063 \\
25.0 & 0.012 & 0.0080 \\
30.0 & 0.014 & 0.0094 \\
35.0 & 0.0166 & 0.0110 \\
40.0 & 0.0185 & 0.0123 \\
45.0 & 0.0208 & 0.0139 \\
50.0 & 0.0226 & 0.0150 \\
55.0 & 0.0245 & 0.0163 \\
60.0 & 0.026 & 0.0173 \\
70.0 & 0.0305 & 0.0203 \\
80.0 & 0.034 & 0.0226 \\
90.0 & 0.038 & 0.0253
\end{tabular}

The curve obtained from Table II $a$ shows a polarization of 0.7 volt, comparable with the value given by Table Ia for platinized electrodes. Table II $b$ shows that with increasing current density metallic aluminum does not deposit from a solution of this concentration. A discharge from 0.013 ampere per 
sq. $\mathrm{cm}$. gave 0.356 volt. Evidently the surface condition of the platinum is a minor factor in depositing aluminum.

In the same solution a current - E. M. F. curve was taken at $18^{\circ} \mathrm{C}$, using aluminum electrodes. The readings are given in Table III, and the curve drawn from them indicates a polarization of 0.8 volt for a current density near 0.00025 ampere per sq. cm. If the aluminum anode were smoothly attacked and aluminum deposited at the cathode there would be no polarization. These aluminum electrodes give approximately the same value as that for platinum electrodes.

TABLE III.

Aluminum Electrodes. $\mathrm{AlBr}_{3}$ in $\mathrm{C}_{2} \mathrm{H}_{5} \mathrm{Br} .4 .38$ percent.

\begin{tabular}{c|l|l}
\hline Volts & Amperes & Amperes per sq. cm. \\
\hline 2.0 & 0.0006 & 0.00015 \\
3.0 & 0.001 & 0.00025 \\
5.0 & 0.002 & 0.0005 \\
7.0 & 0.003 & 0.00075 \\
8.0 & 0.0035 & 0.00087 \\
9.0 & 0.0040 & 0.0010
\end{tabular}

As a check the potential of aluminum was determined in this solution against a platinum cathode at $15^{\circ} \mathrm{C}$. This gave 0.632 volt. This low value, corresponding so closely to the polarization values given by Tables I $a$, II $a$ and III, suggest that we have to do with a coating on the aluminum. To investigate this a current of 0.010 ampere - approximately 0.5 ampere per sq. cm. - was passed between a platinum cathode and an aluminum anode for several minutes, and the discharge taken. This gave the same low value recorded above. However, on reversing the current and using the aluminum as cathode while electrolyzing, the discharge potential for the total cell was 2.235 volts. ${ }^{\mathrm{I}}$ Readings taken at intervals after releasing the impressed E. M. $F$ are given in Table $V$.

${ }^{1}$ Using Poggendorff's compensation method with a d'Arsonval galvanometer sensitive to one-half megohm. 
These values are plotted in Plate I with volts as ordinates and minutes as abscissas. The rapid decrease of discharge pressure with time points strongly to the formation of a film $\mathrm{m}^{23}$ upon

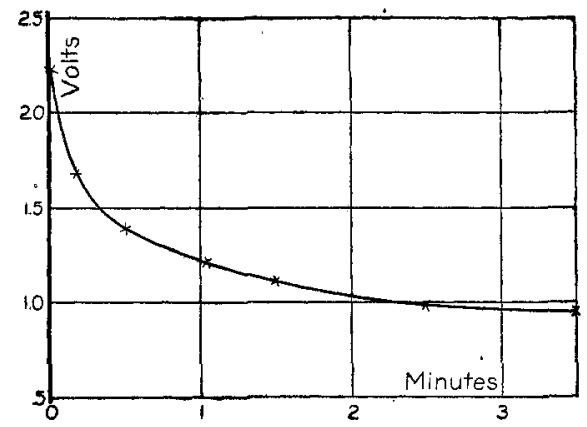

Plate I.

$\mathrm{Al}-\mathrm{Pt}$ in $\mathrm{AlBr}_{3}+\mathrm{C}_{2} \mathrm{H}_{5} \mathrm{Br}$

$4.3^{8}$ percent

$t=15^{\circ}$

TABLE V.

Discharge Potential. Aluminum-Platinum. $\quad \mathrm{AlBr}_{8}$ in $\mathrm{C}_{2} \mathrm{H}_{5} \mathrm{Br}$. $4.3^{8}$ percent. $t=15^{\circ} \mathrm{C}$.

\begin{tabular}{c|c|c}
\hline \hline Minutes & Seconds & Volts \\
\hline 0 & 0 & 2.235 \\
0 & IO & 1.675 \\
0 & 30 & 1.395 \\
I & 30 & 1.117 \\
2 & 30 & 0.980 \\
3 & 30 & 0.952
\end{tabular}

the aluminum. With the exception of an aqueous solution of anmonium chloride, this film has been observed hitherto in solutions of oxygen acids or their salts; and if we consider the

1 "The Alloying of Metals as a Factor in Electroplating." L. Kahlenberg. Electrochemical Industry, I, 6, 20I (I903).

2 "The Physical Characteristics of Metal Deposits." Ibid. I, 6, 204 $(1903)$.

3 "The Corrosion of Aluminum and Its Prevention." W. R. Mott. Ibid. II, 4, I29 (I904). 
water, as we should, in that case also we have oxygen. Here the only oxygen present is a minute trace due to action of the moisture in the air upon the constituents of the solution during a transfer which was well nigh unavoidable; and below it is shown that this trace is insufficient to induce the formation of a film. Consequently we have a case where aluminum forms a protective coating in a solution containing a halogen radical, and in which the halogen salt of aluminum is soluble to a marked degree.

\section{II.}

A fresh sample of aluminum bromide was prepared by pass ing bromine over aluminum turnings in a hard glass tube heated to redness. The crude product was redistilled, the first few fractions rejected, and the final runnings ${ }^{x}$ dissolved in ethyl bromide, which was also my own preparation, dried over fused calcium chloride and distilled. At $20^{\circ} \mathrm{C}$ the solution had a specific gravity of $1.67 \mathrm{I}$, and analysis gave 0.799 gram of $\mathrm{Al}_{2} \mathrm{O}_{3}$ in I0.2I4 grams of solution, the equivalent of 4.183 grams of $\mathrm{A} \mathrm{Br}_{3}$, giving 40.95 percent of $\mathrm{AlBr}_{3}$ by weight upon the total weight of solution. This corresponds to one gram-molecule in 0.39I liter, or one gram-equivalent in 0.I 27 liter.

The solution was electrolyzed in a cell made of a small widemouth bottle (A, Fig. I), through whose stopper passed two glass tubes ( $\mathrm{I}$ and $\mathrm{J}$ ) with polished platinum electrodes each one-half square centimeter in area fused in their lower ends. A third perforation in the stopper permitted a U-tube (B) packed with ignited asbestos wick to dip into the solution. The outer end of this U-tube was led through a stopper into a second portion of this same solution ( $\mathrm{AlBr}_{3}$ in ethyl bromide) contained in the short test-tube, C. A second U-tube filled with ignited asbestos fiber (D) connected this second aluminum bromide solu-

${ }^{1}$ On allowing the liquid aluminum bromide to solidify, crystais were formed. Some of these had planes nearly one-fourth square centimeter in area; they belong in the rhombohedral division of the hexagonal system, and resemble calcite. The purified aluminum bromide is not white, but a very light yellow. 
tion with a solution of aluminum bromide in absolute ethyl alcohol contained in the test-tube, $\mathrm{E}$; and a third asbestos filled tube $(F)$ gave contact between this alcohol solution and the small beaker $(\mathrm{G})$ containing $\mathrm{O}$. I normal aqueous potassium chloride into which the siphon (L) of an Ostwald half cell (H) dipped. With the exception of the potassium chloride, all solutions were protected from the air by tightly-fitting stoppers of pure rubber and the two protection vessels effectually prevented diffusion of water into the electrolytic cell, while they also afforded electrical connection between the electrodes in the cell (A) and the Ostwald electrode $(\mathrm{H})$.

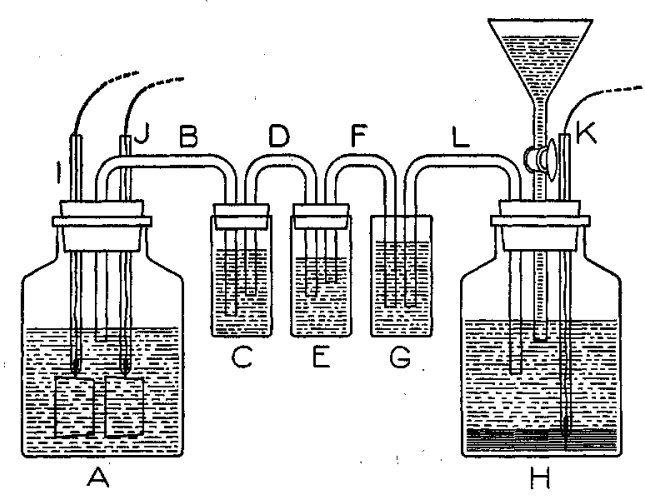

Fig. I

Having thus constituted the system, pressure from a storage battery, regulated by a water rheostat, was applied to the cell through mercury contact in the tubes $I$ and $J$ and the voltage drop across (I) the total cell, (2) anode to Ostwald cell and (3) cathode to Ostwald cell taken on a potentiometer, using Poggendorff's method, while the current passing through the cell was also read. This current when small was gotten by taking the voltage - by compensation - across a known resistance placed in series with the cell, and calculating current from Ohm's law. The electrical connections were similar to those given in full in a previous paper. ${ }^{1}$ Two zero instruments were used; one a

I "Decomposition Curves of Lithium Chloride in Various Alcohols, Etc." Patten and Mott. Jour. Phys. Chem. March, I904. 
portable d'Arsonval, sensitive to one-half megohm; the other a mirror form of d'Arsonval with a figure of merit near $2.00 \times 10^{-8}$. For readings on the total E. M. F. across the cell, and for determining the voltage used to calculate the current passing through the cell, the portable instrument served every purpose, but the resistance of the intermediate vessels $\mathrm{B}, \mathrm{C}, \mathrm{D}, \mathrm{E}, \mathrm{F}, \mathrm{G}, \mathrm{L}, \mathrm{H}$, used to get the anode and cathode voltage drop, was so great that the portable galvanometer gave only a very coarse adjustment. The mirror galvanometer was then used to get the accurate setting. The electrodes were heated to redness before use.

The readings are given in Table VI. Column I contains the total E. M. F. impressed upon the cell; column II, the voltage drop across anode to half-cell, correction being made for the $-0.5^{6}$ volt of the latter; column III, the cathode to half-cell voltage drop, also corrected for the -0.56 volt; column IV, the current density in amperes per square centimeter corresponding to the impressed E. M. F. given in column I; and column V, the current in amperes from which column IV is calculated.

TABLE VI.

Aluminum Bromide in Ethyl Bromide 40.95 percent. $t=20^{\circ} \mathrm{C}$.

\begin{tabular}{|c|c|c|c|c|}
\hline \multicolumn{3}{|c|}{ Volts } & \multicolumn{2}{|c|}{ Amperes } \\
\hline $\begin{array}{c}\text { I. } \\
\text { Total }\end{array}$ & $\begin{array}{c}\text { II. } \\
\text { Anode }\end{array}$ & $\begin{array}{c}\text { III. } \\
\text { Cathode }\end{array}$ & $\begin{array}{l}\text { IV. } \\
\text { Current } \\
\text { density }\end{array}$ & $\begin{array}{c}\text { V. } \\
\text { Current }\end{array}$ \\
\hline 0.3007 & & 0.790 & 0.0000270 & 0.0000135 \\
\hline 0.785 & $-\mathrm{I} .05 \mathrm{O}$ & -0.364 & 0.0000890 & 0.0000445 \\
\hline 1.024 & $-\mathrm{I} .230$ & -0.160 & 0.000298 & 0.000149 \\
\hline $\mathrm{I} .44 \mathrm{I}$ & -- I. 295 & +0.217 & 0.001072 & 0.000536 \\
\hline $1.85^{\circ}$ & - I. 434 & +0.365 & 0.00230 & 0.00 I I 5 \\
\hline 2.350 & -1.310 & +1.018 & 0.001386 & 0,000693 \\
\hline 2.400 & $-\mathrm{I} .333$ & $+\mathrm{I} .03 \mathrm{I}$ & 0.00144 & 0.000720 \\
\hline 2.578 & -I.440 & +1.116 & 0.00240 & 0.00120 \\
\hline 2.852 & - I. 598 & + I.166 & $0.005^{\circ} 4$ & 0.00252 \\
\hline 3.16 & -1.773 & $+\mathrm{I} .32 \mathrm{I}$ & 0.00680 & 0.00340 \\
\hline 3.50 & -2.040 & $+\mathrm{I} .53 \mathrm{I}$ & 0.01016 & 0.00508 \\
\hline 4.23 & $-2.3^{8} 7$ & $+\mathrm{I} .7 \mathrm{OI}$ & 0.01548 & 0.00774 \\
\hline $7 \cdot 37$ & -5.25 & - & 0.042 & $0.02 \mathrm{I}$ \\
\hline 9.70 & - & +4.10 & $0.05^{8}$ & 0.029 \\
\hline Discharge & $-0.8 \mathrm{I}$ & $+0.8 \mathrm{I}$ & & \\
\hline
\end{tabular}


Table VI is graphically represented in Plate II. Ordinates are in amperes per square centimeter of electrode surface. ${ }^{\mathrm{T}}$ The curve "Total" was gotten from column I and column IV, and shows the variation of current density with increasing E. M. F. Since the two platinum electrodes dipping into the solution op-

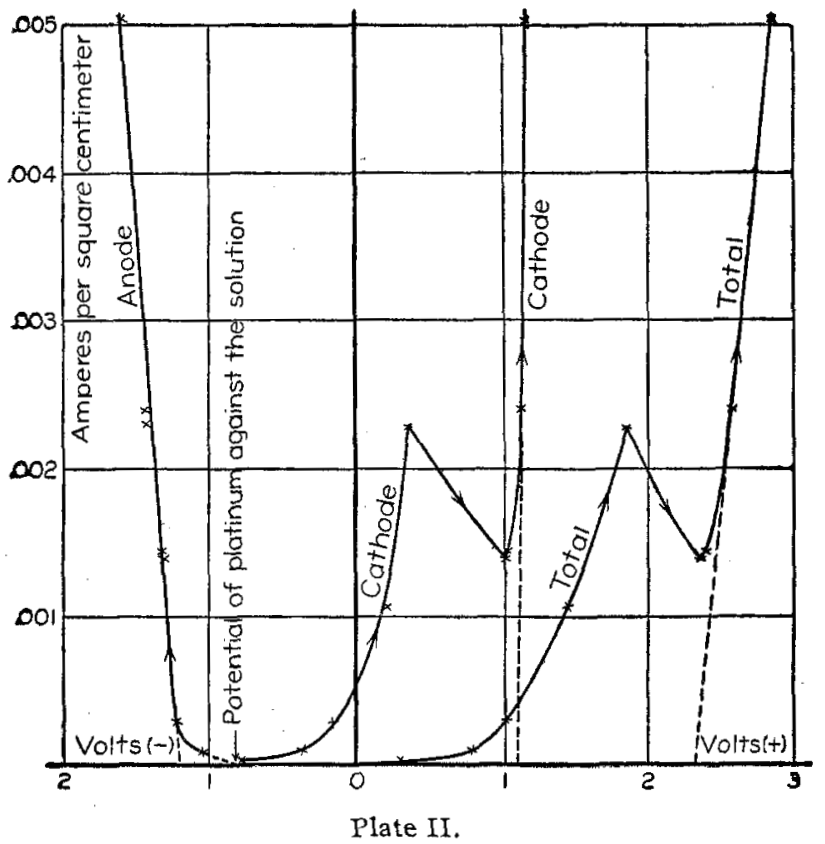

$\mathrm{AlBr}_{3}$ dissolved in $\mathrm{C}_{2} \mathrm{H}_{5} \mathrm{Br}$

40.95 percent

Platinum electrodes

$t=20^{\circ} \mathrm{C}$.

pose each other, with zero impressed E. M. F. the cell shows no polarization, and the curve rises from the zero point of the chart. The current density increases rapidly with the F. M. F. until a value 0.0023 ampere per sq. $\mathrm{cm}$. is reached. Near this point aluminum is deposited faster than the solution can redissolve it, its counter E. M. F. is exerted, and in consequence the current density falls off until the impressed E. M. F. rises beyond 2.3

${ }^{1}$ In this case the anode and cathode were both of the same area. 
volts when the curve becomes the straight $C R$ line of the conducting solution.

The curve "Cathode" is plotted from columns III and IV. It rises, not from zero, but from the value of platinum against the solution, -0.8 volt. "The similarity between curves "Total" and "Cathode" is apparent at a glance, and is due to the fact that the reaction at the cathode is manifest in the total curve for the cell.

The "Anode" curve also rises from -0.8 volt, as would be expected, but since only one pronounced reaction-the liberation of bromine-occurs, the curve becomes a $\mathrm{CR}$ line after reaching the current density 0.000 I 5 ampere, at which sufficient bromine is deposited to give the polarization $-\mathrm{I} .20$ volt, its single potential against the solution.

Producing the CR lines of these three curves to the axis of volts gives a single potential for aluminum of + I.I volts; for bromine, - I. 2 volts; and a polarization of +2.3 volts for the cell as a whole. The agreement of this value with the instantaneous discharge potential given in Table $\mathrm{V}$ and Plate $\mathrm{I}$ is excellent, and of course to be expected. The rapid decrease in the discharge potential with time indicates, too, why the single discharge potentials for anode and cathode given in Table VI are lower than those gotten by extending back their respective $\mathrm{CR}$ lines in Plate II.

Aluminum was deposited in crystals treeing out from the edges of the cathode. The metal reacts upon the solution vigorously, giving off a gas-probably largely $\mathrm{C}_{4} \mathrm{H}_{50}$. It has been shown that aluminum coated by standing in the air is not readily

1 Compare with the value $-0,83$ volt for platinum against lithium chloride in water (Jour. Phys. Chem. March, I904, pages 162 and 163). This single potential is usually. attributed to oxygen in the platinum. If that be assumed here as true, we have a partial explanation of the formation of a film and the failure to deposit aluminum from dilute solutions of aluminum bromide in ethyl bromide. Still, having this apparent oxygen potential also in concentrated solution, we have no indication of a film; the aluminum deposits in a regular manner and is redissolved because of its action upon the ethyl bromide as partially expressed by the equation :

$$
2 \mathrm{Al}+6 \mathrm{C}_{2} \mathrm{H}_{5} \mathrm{Br}=2 \mathrm{AlBr}_{3}+3 \mathrm{C}_{4} \mathrm{H}_{10} \text {. }
$$


acted upon by this solution. The voltages, of course, vary correspondingly. This is considered more fully under the head "Aluminum as Anode."

By quickly shifting the electrodes from the solution to 95 percent ethyl alcohol scales of aluminum were removed from the cathode. The metal is coated with a film and dull. It does not adhere to the platinum, but strips readily. Hydrochloric acid dissolved the metal with evolution of hydrogen.

At the anore bromine is liberated and diffuses rapidly, thus rendering difficult the deposition of aluminim in quantity without a diaphragm. The platinum electrode showed no sign of corrosion.

\section{Aluminum as anode}

Isenburg $^{\mathrm{T}}$ got 60 to 47 volts counter pressure from an aluminum anode. This he most reasonably explained as a condenser effect caused by the high resistance film upon the anode. S. R. Cook, ${ }^{2}$ repeating the work of Isenburg, which he seems to have overlooked, attributes this action of the aluminum anode in aqueous solutions of oxy-salts and acids to an accumulation of ions which set up a higher counter E. M. F. by reason of their. inability to discharge through this high resistance film. He gives 7.5 volts counter pressure from 26 volts applied during one hour, seven minutes and thirty seconds. In that time the current fell off from 9.000 amperes to 0.070 ampere. Air bubbled over the anode caused the current to rise to 0.35 ampere; when the air current was interrupted the current fell again to 0.07 ampere. The solute used was potassium aluminum sulphate.

The distinction between Isenburg's explanation and that of Cook is not deep seated. Both require the film. The solution in contact with the film may be constituted of small particles of atomic magnitude, or it may not; likewise the film. This whole situation may be expressed thus: when used as anode in certain solutions aluminum becomes coated with a protective

${ }^{1}$ Zeit. f. Elektrochemie, 9, 278-280 (1903).

"Physical Review, 18, 23 (1904). 
film $\mathrm{m}^{\mathrm{x}}$ of high resistance which hinders the passage of the current. The observed condenser action is only what is to be expected, having two conductors separated by a dielectric. The breaking down of the film under high voltage and the effect of temperature upon this "critical" voltage are normal phenomena, easily comprehended aside from assumptions. F. Fischer ${ }^{2}$ has shown the effect of temperature upon this penetration of the film; and its breakdown is seen to be merely a question of concentrating enough energy upon it to force a passage, or to secure a temperature sufficient to cause its solution in the electrolyte. It is doubtful if even a true electrolytic capacity ${ }^{3}$ gains vividness by expression in terms of the ionization theory, inasmuch as it is due to the products of electrolysis discharging out of phase with the current which deposited them; and we need not assume ionization in order to treat the effect upon the wave form mathematically. In the case of the high discharge of Isenburg we have certainly a charge upon the solution, and another upon the aluminum anode; but it by no means follows that in the solution this charge resides upon ions. Experimental data upon ionic migration shows a change in concentration of the solute as a whole. There is nothing in the work of Isenburg or of Cook or of Fischer which necessitates the assumption that uncombined electrically charged negative radicles are massed about the anode. The more light we have upon the behavior of aluminum, the closer we come to a purely material problem;

${ }^{1}$ Compare with the high resistance films upon the cathode obtained by electrolyzing lithium chloride in various solvents. This cathode resistance film gave no such high discharge pressure as Isenburg and Cook report for the anode film. If the phenomenon be due to a massing of undischarged ions about the electrode it is to be expected that cations show counter E. M. F. under comparable conditions. The time between release of applied E. M. F. and reading of counter E. M. F. was near one-tenth of a second. It is possible that a shorter time interval would show this condenser effect for the cathode film. These observations are given in a former paper, "Decomposition Curves of Lithium Chloride in Alcohols, Etc. (Jour. Phys. Chem. 8, I53 (1904)) and in a series of abstracts to be found in the Electrochemical Industry, I, I2, August, 1903.

${ }^{2}$ F. Fischer. Zeit. Phys. Chem. 48, I77 (rgo4).

${ }^{3}$ F. Krüger. Ibid. 45, I (IgO3). 
when the conditions requisite for removing the films are met, the metal behaves normally; and these conditions are no more peculiar than for other chemical processes.

The solution of aluminum bromide used in my experiments was free from oxygen in a high degree. And yet a number of points indicate that a film is formed, that we get the anode action of aluminum, and no high discharge pressure :-

(I) Using anode and cathode of aluminum a polarization of 0.8 volt was obtained. Consult Table III.

(2) An aluminum anode against a platinum cathode gave 0.7 volt, even after electrolyzing several minutes; and the current decreased with time.

(3) After a current had been passed for several minutes while the aluminum served as cathode, the same sheet of aluminum used in (2) gave 2.235 volts against platinum. See Plate I, Table V.

(4) The decomposition curves obtained with platinum electrodes show a low polarization value - about 0.8 volt - for rather high current densities; and the discharge potentials are considerably lower, though read within one-tenth of a second after releasing the impressed E. M. F.

(5) The discharge potential 2.235 volts cited in (3) falls off with time - as shown in Table $\mathrm{V}$ and Plate $\mathrm{I}$ - till a value comparable with those given in (I), (2), and (4) is reached.

(6) The decomposition value of 2.30 volts - obtained graphically in Plate II, "Total" curve from data given in Table VI - agrees with the discharge potential given in (5), as well as with the sum of the anode and cathode polarization from Plate II.

(7) Aluminum was obtained and removed from the solution which gave this value, 2.30 volts.

(8) Other metals also show a potential lower than is to be expected in this solution $\left(4.3^{8}\right.$ percent). At $\mathrm{I} 8^{\circ} \mathrm{C}$ magnesium gave a value of 0.797 volt, which rose to $0.83^{8}$ volt; copper, 0.790 volt; lead, I.OI 4 volts; cadmium, 0.846 volt; and zinc, 0.795 volt. These readings are taken against the same platinum 
cathode in each case, and are for the total cell. Platinum itself has a single potential of near -0.80 volt against this solution, as will be seen from Plate II. The effect of a film in decreasing effective voltage is evident.

Table VII gives the influence of change in concentration upon the E. M. F. for magnesium, manganese and aluminum against platinum. Under each metal is given the total $\mathrm{E}$. M. F. for the cell, and at the left is the corresponding percentage composition of the solution by weight. The measurements were made by compensation, using the portable galvanometer previously described.

TABLE VII.

Potential of Metals Against Platinum in $\mathrm{AlBr}_{3}+\mathrm{C}_{2} \mathrm{H}_{5} \mathrm{Br}$

\begin{tabular}{c|c|c|c} 
& & \multicolumn{2}{|c}{ Volts } \\
\cline { 2 - 4 } Percent AlBr & Magnesium & Manganese & Aluminum \\
\hline 49.41 & 1.636 & 0.767 & 0.984 \\
26.8 & $2.277^{1}$ & 0.943 & $0.985^{2}$ \\
18.4 & 2.015 & 0.757 & - \\
14.0 & 1.955 & - & - \\
11.0 & 1.935 & - & - \\
9.5 & 1.920 & - & - \\
8.2 & 1.920 & - &
\end{tabular}

Taking the single potential of bromine against the solution as - I.20 volts from Plate II, the single potential of magnesium against a 26.8 percent solution of aluminum bromide in ethyl bromide is $+\mathrm{I} .077$ volts. Here again manganese and aluminum give low values indicative of film formation. The low voltage 1.575 , given by magnesium in the 26.8 percent solution, is due to the formation of magnesium bromide which is not dissolved away quickly. As soon as this coat is gone we get the higher value, 2.277 . Conversely, by allowing the magnesium

${ }^{1}$ In the 26.8 percent solutions the instantaneous value for magnesium was I. 575 volts, rising quickly to 2.277 volts, the value in the table.

2 This value rapialy fell to +0.582 volt. 
to dissolve until the solution became rich in magnesium bromide the E. M. F. fell to I.500 volts.

The decrease in voltage with increasing dilution is contrary to the needs of Nernst's theory. On the other hand, it seems that we have the voltage passing through a maximum at or near 27 percent of $\mathrm{AlBr}_{3}$ in ethyl bromide. Now Plotnikoff ${ }^{r}$ has shown that the molecular conductivity of $\mathrm{AlBr}_{3}$ in this solvent falls rapidly and then slowly rises with increasing dilution. While of course the conductivity cannot infuence difference of potential gotten by a zero method, still it indicates a change in the nature of the solution which appears to go hand in hand with this maximum E. M. F. of magnesium. Reference to Plotnikoff's concentration curve shows a rapid change in molecular conductivity at these dilutions, and this I have confirmed experimentally. In this connection the point should be made that the dielectric constant of ethyl bromide is only 8.90. This is an excellent illustration of the failure of the Nernst-Thomson rule, for the above solutions conduct well. The combination of solvent and solute to form a new compound can hardly be urged in extenuation, since such union is now very generally conceded in all cases of solution.

Recurring to the work of Cook, ${ }^{1}$ it seems from the experimental data set forth above, that his theory of a counter E. M. F. produced by a layer of ions at the anode is not applicable in this solution. However it is not impossible that at lower concentration of $\mathrm{AlBr}_{3}$ a film of sufficient resistance might be formed upon an aluminum anode to afford this high counter pressure. And it would be desirable to test this, as well as to take the discharge within a shorter time interval.

The use of a fused nitrate ${ }^{2}$ with aluminum anode and iron cathode shows that even at fairly high temperature aluminum

1. c.

${ }^{2}$ Burgess and Hambuechen. Trans. Am. Electrochem. Soc. I, I47 (IgO2) ; Electrochem. Industry, 1, 6, 204 (I903). Cf. W. R. Mott. Ibid, 2, 4, I 29 (1904); also 2, 7, 268 (1904); also C. I. Zimmerman. Trans. Am. Electrochem. Soc. 5, 147 (1904). 
exerts its rectifying action upon an alternating current. This indicates that the film formation is not solely a question of temperature.

\section{Conclusions}

(I) It has been shown that Plotnikoff's values for the conductivity of aluminum bromide dissolved in ethyl bromide are reliable; and his deposition of crystalline aluminum from such a solution has been confirmed.

(2) Crystals of aluminum bromide near 0.5 centimeter on edge were formed from the fused salt. They belong in the rhombohedral division of the hexagonal system, and resemble calcite. The purified aluminum bromide is not white, but a very light yellow.

(3) Decomposition curves for dilute and concentrated solutions of aluminum bromide in ethyl bromide have been determined, with platinized and with polished platinum electrodes, as well as with aluminum electrodes.

(4) Aluminum has a single potential of $+\mathrm{I} . \mathrm{IO}( \pm 0.2)$ volt, neglecting the possible small E. M. F. at the contact of the solutions, against a 40.95 percent solution of aluminum bromide in ethyl bromide; and bromine, a single potential of - I.2O $( \pm 0.02)$ volt.

(5) A current density of 0.0023 ampere per sq. cm. or about two amperes per sq. $\mathrm{ft}$. is just sufficient to compensate for the solvent action of the solution upon the deposited aluminum in the concentrated solution (40.95 percent). A dilute solution ( $4.3^{8}$ percent) failed to yield aluminum even at moderately high current density.

(6) An aluminum anode, which had been stripped of its film electrolytically, gave 2.235 volts in a $4.3^{8}$ percent solution of aluminum bromide in ethyl bromide against a platinum cathode. Similarly magnesium gave 2.277 volts, from which by subtracting $+\mathrm{r} .20$ for bromine we get $\mathrm{r} .08$ volts as the approximate single potential of magnesium against this solution.

(7) A striking exception to the Nernst-Thomson rule is cited, in that ethyl bromide with a dielectric constant of 8.9 
yields a solution of good conductivity with aluminum bromide as solute.

(8) The bearing of this work upon the aluminum anode phenomena is discussed; it appears that a film is formed upon aluminum in a solution very free from oxygen, but the high counter pressure mentioned by Isenburg and by Cook for aqueous solutions has not been found thus far.

(9) Aluminum bromide dissolved in ethyl bromide is found to lack the requirements of a commercial plating solution for the deposition of aluminum.

This work has been carried out in the laboratory of physical chemistry. I wish to thank Prof. Louis Kahlenberg for his continued interest in my work and for the many favors conferred upon me during the past two years. I am also indebted to Prof. G. C. Shaad for the adjustment of my potentiometer resistances, and to Prof. C. F. Burgess and Mr. F. L. Shinn for the use of instruments.

University of Wisconsin, June II, I904. 